\title{
Respons Perilaku Pasar Terhadap Teknologi Informasi di Indonesia dalam Tinjauan Ekonomi Islam
}

\author{
Haryono $^{1}$, Hasnil Hasyim ${ }^{2}$ \\ ${ }^{1,2}$ Sekolah Tinggi Agama Islam Al-Hidayah Bogor \\ haryono.staialhidayahbogor@gmail.com \\ hasnil.alhidayah@gmail.com
}

\begin{abstract}
The market behavior response to the rapidly growing information technology in Indonesia is forcing the market to adapt quickly. In the digital era 4.0, there have been quite extreme changes in business models. Even the giant companies have gone out of business. In the perspective of Islamic economics this phenomenon continues to be studied. In one condition, business growth is growing very fast and on the other hand the fatwas of the ulama are often left behind. This qualitative research is presented with a phenomenological approach and sharia compliance. The data analyzed are secondary data related to the latest facts about the information technology market. The author uses the theory of market behavior change to strengthen this argument. In principle, Islam always gives appreciation to technological developments that aim to facilitate human work, as long as these facilities do not violate the forbidden boundaries. In the perspective of Islamic economics, the focus is on the business schemes that are run and the muamalah contracts that are used whether they meet the requirements and pillars or not. If the conditions and pillars are met then the business can be run. Simply put, please do business using advanced technology but still comply with sharia principles.
\end{abstract}

Keyword: market behavior response, information technology, business model, sharia compliance

\begin{abstract}
ABSTRAK
Respons perilaku pasar terhadap teknologi informasi yang berkembang pesat di Indonesia memaksa pasar untuk segera menyesuaikan diri. Pada era digital 4.0 ini telah terjadi perubahan model bisnis yang cukup ekstrem. Perusahaan raksasa sekalipun banyak yang gulung tikar. Dalam perspektif ekonomi Islam fenomena ini terus dikaji. Pada suatu kondisi pertumbuhan bisnis sangat cepat berkembang dan pada sisi yang lain fatwa-fatwa dari para ulama sering tertinggal di belakang. Penelitian kualitatif ini disajikan dengan pendekatan fenomenologi dan sharia complince. Data yang dianalisis adalah data-data skunder yang terkait dengan fakta-fakta terbaru tentang pasar teknologi informasi. Penulis mengunakan teori perubahan perilaku pasar untuk memperkuat argumentasi ini. Pada prinsipnya Islam senantiasa memberikan apresiasi terhadap perkembangan teknologi yang bertujuan untuk mempermudah pekerjaan manusia, selama sarana tersebut tidak melanggar batas-batas yang diharamkan. Dalam perspektif ekonomi Islam yang menjadi konsentrasinya adalah skema bisnis yang dijalankan dan akad-akad muamalah yang digunakan apakah memenuhi syarat dan rukunnya atau tidak. Apabila syarat dan rukun terpenuhi maka bisnis dapat dijalankan. Sederhananya silakan berbisnis dengan menggunakan teknologi canggih tapi tetap harus comply dengan prinsip-prinsip syariah.
\end{abstract}

Keyword: respons perilaku pasar, teknologi informasi, model bisnis, sharia compliance. 


\section{A. PENDAHULUAN}

Teknologi yang berkembang pesat di Indonesia memaksa pelaku industri dan UMKM untuk menyesuaikan diri. Respons yang lambat dari pelaku industri dan UMKM akan mengancam eksintesi bisnis yang mereka jalankan selama ini. Sepanjang dua tahun ke belakang dari tahun 2020 sampai dengan tahun 2021 telah terjadi perkembangan bisnis berbasis teknologi informasi. Bisnis-bisnis tersebut akhirnya mengerucut pada sebuah nama yang disepakati oleh publik, salah satu di antaranya yang sering kita dengar adalah bisnis online. Macam-macam bisnis online mulai dari transportasi online, online shop, jasa pendidikan online, financial technologi (fintech) dan lainlain. Berkembangnya pasar digital berbasis teknologi informasi selama dua tahun terakhir ini salah satu penyebab terbesarnya adalah pandemi covid-19.

Pandemi covid-19 melanda hampir seluruh negara di dunia ini. Penyebaran covid-19 ini memaksa pemerintah untuk membuat kebijakan-kebijakan strategis dalam upaya mencegah rantai penularan dan menyelamatkan jiwa manusia. Di antara kebijakan-kebijakan yang diberlakukan oleh pemerintah Indonesia adalah PSBB, PPKM, dan lain-lain. Kebijakan itu intinya membatasi pergerakan manusia yang membuat manusia berkerumun sehingga terjadi penularan virus. Dalam pembahasan ini penulis tidak akan panjang lebar membahas pandemi covid-19. Penulis lebih konsen pada dampak pandemi covid-19 yang cukup efektif memaksa manusia untuk menyesuaikan diri melakukan aktifitas bisnis berbasis teknologi informasi.

Kondisi yang memaksa seluruh manusia harus tetap di rumah, membuat aktifitas bisnis secara online berlangsung massif. Masyarakat akhirnya terbiasa membeli barang-barang kebutuhannya secara online. Tidak hanya itu masyarakat yang sebelumnya menjual barang dagangannya secara offline akhirnya mereka menjualnya secara online. Hal itu berlaku pula pada supermarket, ritail, dan jasa, akhirnya mereka terpaksa menjual barang-barangnya secara online. Begitu pula dengan lembaga pendidikan seperti sekolah, kampus, lembaga kursus dan lain-lain. Anak-anak sekolah mulai dari tingkat sekolah dasar sampai dengan sekolah menengah melakukan pembelajaran secara online (daring), demikian juga dengan mahasiswa mereka juga melakukan pembelajaran secara online. Aplikasi-aplikasi yang digunakan seperti google classroom, google meet, zoom, dan seterusnya terus mengalami perkembangan. 
Lembaga-lembaga kursuspun saat ini banyak yang online seperti ruang guru, English first, dan lain-lain. Aplikasiaplikasi berbasis online yang ditawarkan pun betul-betul canggih. Aplikasi-aplikasi tersebut support terhadap kebutuhan manusia. Bahkan saat ini masyarakat secara luas mulai merasakan dan menikmati kegiatan-kegiatan mereka sehari-hari secara online. Rapat, seminar, reunian, silaturahmi dengan keluarga di hari raya pun banyak dilaksanakan secara online.

Namun tidak semua kegiatan ekonomi yang berjalan secara online ini mematuhi prinsip-prinsip syariah. Banyak sekali transaksi-transaksi yang mereka jalankan yang melanggar prinsip-prinsip syariah. Ummat Islam perlu menyadari bahwa perkembangan teknologi informasi yang sangat canggih pesat ini terkadang berbanding lurus dengan pelanggaranpelanggaran syariat. Untuk itu diperlukan pedoman-pedoman dari ulama agar masyarakat mengetahui Batasanbatasannya. Dalam kesempatan ini penulis akan fokus pada pembahasan tentang respons perilaku pasar terhadap teknologi informasi di indonesi dalam tinjauan ekonomi Islam.

\section{B. TINJAUAN PUSTAKA}

Pada prinsipnya Islam telah mengatur kegiatan bisnis yang dijalankan manusia dengan sebaik-baiknya. Dalam Islam keuntungan itu hanya dapat diraih dengan tiga hal; yang pertama jual-beli, yang kedua bagi hasil, dan yang ketiga adalah jasa. Ketiga prinsip ini mencakup secara luas seluruh transaksi yang dijalankan oleh manusia. Prinsip-prinsip syariah ini sesungguhnya akan mencegah manusia dan menyelamatkan manusia dari transaksi-transaksi yang haram seperti riba, ghoror, maisir, haram, zalim, curang, monopolistik, riswah, dan seterusnya. Transaksi-transaksi haram ini pada hakikatnya sangat merugikan manusia secara bisnis, dan merugikan manusia pada sisi ukhrowinya juga. Setiap perbuatan yang melanggar prinsip-prinsip syariah akan dimintai pertanggungjawaban kelak pada hari kiamat.

Seiring bisnis yang terus mengalami perkembangan, para ulama pun akhirnya menerbitkan fatwa-fatwa terkait dengan akad-akad muamalah. Akad-akad yang telah diterbitkan oleh para ulama di antaranya adalah akad jual beli yang meliputi, murabahah, salam, istishna, akad bagi hasil yang meliputi, musyarakah, mudarabah, akad jasa yang meliputi ijarah, ijarah muntahiya bittamlik, dan ijarah multijasa. Akad-akad ini sudah digunakan oleh perbankan syariah, asuransi syariah, pegadaian syariah, koperasi syariah, BMT, pasar 
modal syariah, reksadana syariah, fintech syariah, finance syariah, dan lain-lain.

Akad-akad ini juga digunakan oleh perusahaan-perusahaan besar yang menjalankan kegiatan usahanya berdasarkan prinsip-prinsip syariah. Perusahaan-perusahaan yang menjalankan kegiatan usahanya berdasarkan prinsip-prinsip syariah maka wajib memiliki Dewan Pengawas Syariah yang berjumlah 3 orang. Tugas DPS tersebut untuk menjamin dan memastikan bahwa kegiatan usaha yang dijalankan comply (patuh) pada prinsip-prinsip syariah. Kegiatan bisnis di Indonesia yang menjalankan kegiatan usahanya berdasarkan prinsip-prinsip syariah masih terbilang sedikit. Tingkat kesadaran masyarakat juga masih rendah. Hal tersebut disebabkan mereka tidak mau ribet dengan akad-akad syariah yang hanya akan membatasi transaksi bisnis mereka dan berpotensi mengandung kerugian. Pinjaman online misalkan, bisnis ini banyak menjerat manusia pada transaksi riba yang berbahaya. Namun mereka enggan menjalankan bisnis tersebut dengan prinsip-prinsip syariah karena dibatasi oleh banyak hal. Misalkan dana yang dipinjam harus digunakan untuk kebutuhan yang halal baik itu pada sektor produktif maupun konsumtif. Kemudian instrument yang digunakan adalah bagi hasil bukan bunga, dan seterusnya.

Prinsip-prinsip syariah pada hakikatnya suitable terhadap teknologi informasi. Kecanggihan teknologi informasi di era digital sangat membantu mempermudah kegiatan manusia. Apabila prinsip-prinsip syariah dijadikan bagian terpenting pada bisnis-bisnis berbasis teknologi informasi di era digital ini maka bisnis akan bergembang sebagaimana mestinya dan aman dari unsur riba, ghoror, dan maisir.

\section{METODE}

Dalam memecahkan masalah ini penulis menggunakan jenis penelitian kualitatif analitik. Penulis melakukan analisis secara mendalam terkait dengan permasalahan sosio-ekonomi yang berkembang di masyarakat. Untuk mendapatkan hasil yang maksimal penelitian ini menggunakan pendekatan fenomenologi. Jenis pendekatan ini mengamati gejala sosial yang timbul dan dirasakan oleh masyarakat luas. Permasalahan dikaji berdasarkan tinjauan ekonomi syariah. Tahapan analisis data dilakukan secara bertahap mulai dari proses klasifikasi data, reduksi data, dan penarikan kesimpulan. Penulis berusaha menggambarkan suatu kondisi bisnis berbasis digital yang mengharuskan tetap mematuhi prinsip-prinsip syariah. 
Validasi data menggunakan metode trianggulasi data untuk mendapatkan kualitas makna dari setiap data-data yang dikumpulkan dengan.

\section{HASIL PEMBAHASAN \\ 1. Isi Hasil dan Pembahasan}

Kecanggihan teknologi informasi yang berkembang pesat di dunia membuat manusia berkeinginan untuk memaksimalkan mendukung pekerjaannya. Manusia berusaha melihat setiap kebutuhan yang terkait dengan dirinya diadaptasikan dengan teknologi canggih yang sudah tersedia. Mulai dari kegiatan belanja sehari-hari untuk kebutuhan pokok masyarakat sudah mulai mengandalkan teknologi canggih dengan berbelanja secara online di online shop yang sudah tersedia di aplikasi. Kebutuhan terkait dengan transportasi masyarakat juga sudah banyak menggunakan transportasi online yang dirasa lebih efektif dan efisien dibandingkan dengan transportasi umum, jika mereka menggunakan transportasi umum repotnya adalah mereka terkadang harus berjalan dari rumah ke jalan besar atau naik turun beberapa kendaraan untuk sampai pada tempat tujuan, hal ini berbeda manakala mereka menggunakan transportasi online, mereka tinggal pesan melalui aplikasi dan langsung jemput dari rumah atau dimana kita standby dan langsung diantar sampai tempat tujuan. Jenis kendaraan yang dibutuhkan pun dapat disesuaikan, apakah menggunakan kendaraan beroda dua atau beroda empat tergantung kebutuhan. Kemudian kegiatan manusia yang suka kulineran, makan-makan yang enak itupun juga bisa dipesan melalui aplikasi, kita tidak perlu capai-capai pergi ke restaurant yang memakan banyak waktu, kita tinggal pesan dan pesanan diantar sampai rumah. Begitu pula bagi masyarakat yang berkebutuhan untuk melakukan rapat, seminar, workshop, dan lain-lain juga dapat dilaksanakan dari rumah masingmasing, tidak perlu datang ke tempattempat tersebut. Bahkan apabila kegiatan tersebut melibatkan orang-orang dari luar negeri juga dapat dilaksanakan dengan menggunakan aplikasi tanpa harus pergi ke luar negeri. Kemudian sekolah, kampus, tempat kursus, dan lembagalembaga pendidikan sudah menerapkan belajar secara daring, dimana guru dan murid tidak perlu bertemu di kelas, kemudian masih banyak lagi hal-hal yang dapat dilakukan dengan menggunakan teknologi canggih ini. Dahulu apabila seseorang ingin punya took untuk menjajakan barang dagangannya, makai a perlu membeli sebuah toko, kios, atau ruko, atau minimal mereka harus sewa dengan biaya yang sangat mahal, karena pada umumnya tempat-tempat jualan 
harus berada pada lokasi yang sangat strategis, lokasi yang di sana banyak orang yang berkumpul, belum lagi ia haru menyiapkan barang dagangannya, ia harus membeli barang dagangan terlebih dahulu untuk dijual di toko, kemudian ia juga harus menggaji beberapa karyawan sebagai pelayan toko, apabila toko tersebut besar maka ia memerlukan seorang satpam untuk menjaga toko tersebut. Tentunya bisnis model lama seperti ini membutuhkan modal yang cukup besar, walaupun terkadang tidak sesuai dengan keuntungan yang diraihnya.

Zaman itu telah berganti, di era digital ini siapapun mudah membuka toko online hanya dengan bermodalkan smartphone dan koneksi internet. Ia bisa melakukan bisnis apa saja, bahkan ia bisa membuka toko online secara gratis tinggal mendownload aplikasi dan menginstall aplikasi tersebut, dan ia bisa menjualkan barang-barang milik orang lain dari tokonya, ketika ada yang memesan ia tinggal mengirimkan barang-barang tersebut. Sedemikian canggihnya, modelmodel bisnis seperti ini saat ini sudah banyak dilakukan oleh masyarakat mereka berjualan sesuai dengan pesanan, dan sistem pemasaran melalui online juga tidak kalah dahsyat dengan sistem pemasaran manual seperti zaman dulu.

Berkembang pesatnya teknologi canggih ini memudahkan manusia untuk melakukan aktifitas bisnis, mulai dari jual beli, jasa, bagi hasil, dan lain-lain. Semuanya dapat dilakukan dengan mudah, efektif dan efisien. Namun yang perlu digarisbahawi adalah bahwa bisnisbisnis yang dijalankan tetap harus sesuai dengan prinsip-prinsip syariah, sehingga akan terhindar dari riba, gharar, dan maisir. Hal ini yang harus disadari oleh masyarakat secara luas. Canggih boleh tapi tetap halal.

\section{Prinsip-Prinsip Syariah Pada Transaksi Jual Beli Online}

Pada prinsipnya jual beli baik secara online maupun offline dalam Islam hukumnya sama-sama boleh. Sisi yang membedakan adalah kejelasan atau ketidak jelasan fisik barang. Jual beli secara offline memiliki kelebihan dari sisi ini, dimana penjual lebih mudah menjelaskan barang dagangannya kepada pembeli, dan pembeli dapat melihat dengan jelas barang yang akan dibelinya. Praktik jual beli secara offline membuat penjual kesulitan untuk menyembunyikan cacat pada suatu barang, karena barang tersebut terlihat dengan jelas. Praktik jual beli di pasar tradisional misalkan, betapa ibu-ibu sangat memiliki keleluasaan untuk memilih bumbu dapur atau sayuran yang ingin dibelinya. Ketika mereka menemukan sedikit cacat saja, maka barang tidak akan dipilih atau diambil. 
Namun hal tersebut berbeda dengan jual beli yang dilakukan secara online, pembeli hanya dapat melihat barangbarang tersebut melalui handphone atau laptopnya. Barang-barang yang ditawarkan secara online akan didesain secantik mungkin yang membuat orang akan tertarik dan membeli barang tersebut. Pada saat pembeli merasa cocok dengan barang tersebut ia langsung membelinya, dan pada saat kiriman barang tersebut sampai ke rumahnya ia kecewa, karena ternyata barang yang dilihat di online tidak sama dengan kenyataan. Pada saat ia mau complain sulit. Walaupun tidak semua barang yang dijual secara online adalah barang yang jelek. Namun potensi untuk menipu dan mengelabuhi manusia ada.

Kemudian yang sering terjadi apabila kedapatan barangnya rusak biasanya tidak dapat diganti atau penjual tidak mau mengganti barang dagangannya yang rusak dan sudah diterima oleh pembeli. Biasanya pedangan memberikan solusi bahwa ia akan mengganti barang yang rusak apabila pembeli membeli salah satu barangnya dengan harga yang sama. Nah pada perbuatan itu ada unsur zalim.

Ada beberapa hal yang perlu diperhatikan apabila kita ingin melakukan bisnis online pada sektor jual beli; 1) penjual hendaknya hanya menjual barangbarang yang berkualitas. Hal tersebut untuk mengantisipasi apabila pembeli kecewa lantaran barang yang ia beli tidak sesuai dengan aslinya, atau ketika barang itu digunakan ternyata tidak awet. Hal tersebut akan mempuat pembeli menjadi kecewa dan tidak akan belanja lagi di toko online tersebut. 2) hendaknya penjual menjelakan secara rinci barang yang dijualnya, baik dari segi ukuran, bentuk, warna, volume, bobot, rasa, tekstur, dan hal-hal yang melekat pada barang tersebut. Sehingga dengan demikian pembeli mendapatkan gambaran yang komprehensif tetang hakikat barang tersebut, dan hal itu dapat menumbuhkan truts calon pembeli. 3) Hendaknya pembeli tidak menutupi aib atau cacat pada barang tersebut, sekecil apapun aib itu. Fitroh manusia yang lurus cenderung menyukai keindahan, kesempurnaan, kualitas, dan kenyamanan, sehingga ia rela mengeluarkan uang berapapun untuk mendapatkan barang tersebut. 4) Hendaknya transaksi jual beli dilakukan secara tunai. Hal tersebut untuk meminamalisir praktik riba di dalamnya. Dalam jual beli yang dilakukan secara kredit, pada umumnya penjual membebankan bunga kepada pembeli manakala angsurannya telat, dan hal tersebut termasuk riba. 5) Hendaknya barang-barang yang dijual adalah barangbarang yang jelas kehalalannya. Dengan memperhatikan kelima hal tersebut maka 
transaksi jual beli yang dilakukan secar online akan aman dari unusr riba, ghoror, dan maisir.

\section{Prinsip-Prinsip Syariah Pada Transaksi Jasa Online}

Bisnis pada sektor jasa yang dilakukan secara online banyak sekali jumlahnya. Pada prinsipnya transaksi jasa yang dilakukan secara online sama dengan transaksi jasa yang dilakukan secara offline. Konsultasi Kesehatan misalkan, saat ini seorang pasien dapat melakukan konsultasi secara online dengan seorang dokter. Konsultasi tersebut dilakukan secara online menggunakan aplikasi. Hal itu tidak terlalu berbeda dengan konsultasi yang dilakukan secara offline. Namun pada jasa pendidikan online atau kursus online maka disana ada sedikit perbedaan. Yang membedakan adalah proses transfer ilmu secara online dirasa kurang efektif, karena seorang murid cenderung kurang serius karena tidak ada guru yang mengawasinya secara langsung. Seorang guru cenderung seperti seorang robot yang melakukan aktifitas satu arah, sementara dalam dunia pendidikan guru melakukan kegiatan pembelajaran dua arah. Jadi hasil dari pendidikan online sesungguhnya kurang efektif dalam mencapai pembelajaran. Selain itu masih banyak lagi jasa-jasa yang ditawarkan secara online. Pada prinsipnya yang perlu ditekankan adalah benefit yang dapat dirasakan oleh orang yang menggunakan jasa tersebut. Pelaku bisnis pada sektor jasa yang dilakukan secara online harus menjamin kepuasan pengguna.

\section{Prinsip-Prinsip Syariah Pada Transaksi Bagi Hasil Online}

Pada sektor bagi hasil atau yang lebih dikenal dengan investasi adalah sektor bisnis yang sangat rawan baik dilakukan secara online dan offline. Kebanyakan skema yang ditawarkan adalah skema bunga. Model investasi yang berjalan biasanya hanya melihat 2 sisi saja. Sisi yang pertama bagaimana modal yang saya investasikan pada suatu perusahaan dapat kembali dalam rentang waktu yang sangat cepat dan aman, kira-kira dalam hitungan satu tahun, dua tahun, atau tiga tahun. Ketika modal yang sudah diinvestasikan sudah kembali maka berapa capital gain yang didapat, apakah nilai modalnya bertumbuh atau tidak. Sisi yang kedua adalah bahwa ketika seseorang ingin berinvestasi pada sektor bisnis tertentu yang ia pikirkan adalah apakah perusahaan tersebut berani memberikan keuntungan yang lebih besar dari bunga deposito atau tidak. Biasanya mereka mematok keuntungan yang cukup besar.

Ada dua hal yang paling bermasalah disini, yang pertama investor ingin modalnya bertumbuh dan dapat keuntungan besar tanpa mau memikirkan risikonya. Praktik investasi seperti ini 
jelas-jelas mengandung unsur riba dan maisir yang sangat membahayakan. Dalam Islam sistem bagi hasil adalah kerjasama kedua belah pihak pada suatu bisnis yang halal. Kemudian kedua pihak tersebut sama-sama berkontribusi modal. Apabila ada keuntungan maka dibagi sesuai dengan porsi bagi hasil yang disepakati, apabila rugi maka kerugian ditanggung bersama. Itu adalah sistem yang sangat adil dalam perspektif Islam.

\section{Isi Hasil Pembahasan}

Berdasarkan pembahasan di atas penulis berpendapat bahwa Islam sangat mendukung teknologi informasi yang terus berkembang dengan pesat. Teknologi informasi dalam Islam merupakan sarana yang dapat membantu memudahkan urusan manusia. Selama sarana tersebut digunakan untuk tujuan yang halal, maka hukum sarana tersebut menjadi halal, tetapi jika sarana tersebut digunakan untuk tujuan yang haram, maka sarana tersebut berubah menjadi haram. Dalam kegiatan bisnis teknologi informasi memberikan peran yang sangat penting bagi sistem perekonomian. Teknologi informasi secara umum memberikan support terhadap bisnis yang dijalankan oleh manusia, baik dari sektor jual beli, jasa, dan investasi (bagi hasil ).

Pada hakikatnya transaksi bisnis yang dilakukan di tiga sektor tersebut sama saja baik secara online maupun secara offline.
Yang perlu didalami adalah skema bisnisnya, apakah sesuai dengan prinsip syariah atau tidak. Selama sesuai dengan prinsip syariah, maka bisnis tersebut aman untuk dijalankan. Oleh karena itu para ulama diminta untuk mempersiapkan infrastruktur bisnis yang berkembang secara cepat melaluai jaringan ini. Fatwafatwa ulama yang diterbitkan paling tidak memberikan batasan-batasan (ramburambu syariah) untuk dijadikan pedoman.

\section{KESIMPULAN}

Respons perilaku pasar terhadap teknologi informasi dalam perspektif ekonomi Islam masih minim. Data di lapangan menunjukkan bahwa bisnis online berkembang pesat sementara fatwa-fatwa tentang kegiatan bisnis yang dilakukan secara online masih sedikit. Namun demikian tidak sedikit ulama yang membahas perkembangan bisnis online ini dari aspek syariahnya. Pada hakikatnya bisnis yang berkembang lebih kepada jual beli, jasa, dan bagi hasil. Dari ketiga sektor tersebut banyak sekali jenis-jenis bisnis yang dijalankan, jual beli misalkan ada yang dilakukan secara tunai dan kredit. Jual beli secara tunai dengan sistem transfer pada prinsipnya tidak bermasalah, yang bermasalah kemudian adalah jual beli yang dilakukan secara kredit. Masalah yang timbul pada kredit tidak lepas dari skema bunga. Timbul riba dari 
transaksi ini. Kemudian riba juga terjadi pada aplikasi-aplikasi deposit uang elektronik yang digunakan untuk belanja. Bagi pembeli yang menggunakan uang elektronik untuk berbelanja biasanya akan mendapat diskon khusus dari perusahaan aplikasi tersebut. Skema ini biasanya mengandung unsur riba, karena secara tidak langsung pembeli telah meminjamkan sejumlah uang fisik yang dikonversi menjadi uang tunai, kemudian perusahaan penyedia aplikasi biasanya memanfaatkan uang elektronik dari nasabah-nasabahnya untuk dibungakan, sehingga dari sana perusahaan mendapat sejumlah keuntungan dari bunga, dan dari sebagian bunga tersebut ia berikan diskon kepada nasabah yang mendepositokan uangnya pada layanan aplikasi tersebut. Transaksi semacam ini jelas-jelas riba.

Pada bisnis-bisnis model investasi juga sangat rentan mengandung riba dan judi. Apalagi saat ini banyak sekali aplikasi-aplikasi yang menawarkan investasi-investasi yang skemanya tidak jelas secara syariah. Kaum muslimin harus cerdas dalam berivestasi. Pilih layanan-layanan investasi yang sesuai dengan prinsip-prinsip syariah.

\section{SARAN DAN UCAPAN TERIMAKASIH}

Dalam melakukan aktivitas bisnis yang harus diperhatikan adalah apakah bisnis tersebut memenuhi prinsip-prinsip syariah atau tidak. Para pelaku bisnis harus cermat pula melihat skema bisnis yang dijalankan karena dikhawatirkan model-model bisnis tersebut mengandung unsur riba, gharar, maisir, curang, zalim, monopolistik, pengelabuhan, dan lainlain, apalagi jika produk-produk yang dijual ternyata adalah haram.

Ucapan terimakasih disampaikan kepada pihak Manajemen Pengelola Jurnal Ad-Deenar yang telah memberikan fasilitas kepada penulis untuk mempublikasikan artikel ilmiah tersebut.

\section{DAFTAR PUSTAKA}

Prastiwi, Iin Emy, Tira Nur Fitria. (2021). Konsep Paylater Online Shopping Dalam Pandangan Ekonomi Islam. Jurnal Ilmiah Ekonomi Islam, 7(1): 425-432.

Rachman, Rio Febriannur. (2019). Pengembangan Industri Kreatif Berbasis Media Digital di Surabaya dalam Perspektif Islam. Jurnal Pengembangan Masyarakat Islam, 10(2).

Pramono, Nugroho Heri dan Asri Nur Wahyuni. (2021). Strategi Inovasi dan Kolaborasi Bank Wakaf Mikro Syariah dan Umkm Indonesia di Era Digital. Jurnal Ilmiah Ekonomi Islam, 7(1): 183-194.

Rika, Septiana Putri. (2020). Pengaruh Minat Berwirausaha Dan Self Efficacy Terhadap Kesiapan Berwirausaha Di Era Revolusi Industri 4.0 Dalam Perspektif Ekonomi Islam" (Studi Pada Mahasiswa Fakultas Ekonomi Dan Bisnis Islam UIN Raden Intan 
Lampung Angkatan 2016). Repository UIN Raden Intan Lampung.

Desy Safira. (2020). Bisnis Jual Beli Online Dalam Perspektif Islam. Al Yasini: Jurnal Hasil Kajian Dan Penelitian Dalam Bidang Keislaman Dan Pendidikan, 5(1).

Febriyani, Dian dan Ida Mursidah. (2020). Ekonomi dan Perbankan Syariah di Tengah Era Digital. Muamalatuna: Jurnal Hukum Ekonomi Syariah, 12(2).
Saprianto, Febi. (2020). Dilematis UMKM di Era Digital. Scientific Journal of Reflection: Economic, Accounting, Management and Business, 3(1).

Maadi, Alan Suud. (2018). Digitalisasi Manajemen Pendidikan Islam dan Ekonomi Syariah di Perguruan Tinggi Fikrotuna. Jurnal Pendidikan dan Manajemen Islam, 7(1).

Maghfirah, Fitri. (2019). Perubahan Pasar di Era Disruptif: Analisis Etika Bisnis Islam. At-Tijarah: Jurnal Penelitian Keuangan dan Perbankan Syariah, 1(1). 
Ad-Deenar: Jurnal Ekonomi dan Bisnis Islam, VOL: 5/NO: 02 DOI : 10.30868/ad.v5i02.1682
P-ISSN: 2356-1866

E-ISSN: 2614-8838 